\title{
From the Cochrane Library: Interventions for Necrotizing Soft Tissue Infections in Adults
}

Hadir Shakshouk ${ }^{1}$, MBBS, MSci; Camille Hua ${ }^{2}$, MD; Brandon L Adler ${ }^{3}$, MD; Alex G Ortega-Loayza ${ }^{1}$, MD, MCR

${ }^{1}$ Department of Dermatology, Oregon Health \& Science University, Portland, OR, United States

${ }^{2}$ Department of Dermatology, Hôpital Henri Mondor, Créteil, France

${ }^{3}$ Department of Dermatology, Keck School of Medicine, University of Southern California, Los Angeles, CA, United States

\section{Corresponding Author:}

Alex G Ortega-Loayza, MD, MCR

Department of Dermatology

Oregon Health \& Science University

3303 SW Bond Ave, CH16D

Portland, OR, 97239

United States

Phone: 19196194096

Email: ortegalo@ohsu.edu

(JMIR Dermatol 2022;5(1):e34578) doi: $10.2196 / 34578$

\section{KEYWORDS}

necrotizing soft tissue infections; therapy; intervention; systematic review; infections; management; evidence-based medicine; dermatology; skin infection

Necrotizing soft tissue infections (NSTIs) refer to severe life-threatening bacterial infections involving the dermis, subcutaneous tissue, fascia, or muscle. NSTIs can lead to serious morbidities and mortality. Diagnosis can be challenging, and a high index of suspicion is required. Useful clues include pain out of proportion to skin findings, manifestations of systemic toxicity, and lack of response to systemic antibiotics. While crepitus, hemorrhagic bullae, skin necrosis, skin anesthesia, and symptoms of sepsis are typical of NSTIs, confirming the diagnosis requires surgical exploration [1].

Management entails early surgical debridement coupled with empiric broad-spectrum intravenous antibiotics against both aerobic and anaerobic organisms in addition to intensive care support. Tissue hypoxia and necrosis induced by NSTIs limit the efficacy of systemic antibiotics, rendering surgical debridement the mainstay treatment [1].

A Cochrane review [1] investigated available interventions for NSTIs. The inclusion criteria specified randomized controlled trials of medical or surgical interventions in hospital settings for adults with NSTIs. Adjunctive hyperbaric oxygen therapy was addressed in a prior Cochrane review [2]. The primary outcome measures were mortality within 30 days and occurrence of serious adverse events, whereas the secondary outcomes were survival time as well as long - term morbidity assessed via the Functional Impairment Scale [1].
The authors identified 3 trials comprising 197 participants $(\mathrm{n}=117,62 \%$ men) with a mean age of 55 years. In all trials, patients received the standard of care (ie, surgical debridement, empiric antibiotics, and intensive care support). The used empiric antibiotics were vancomycin, clindamycin, ciprofloxacin, and piperacillin-tazobactam [1]. One trial compared 2 antibiotic treatments, moxifloxacin $400 \mathrm{mg}$ once daily and amoxicillin - clavulanate $3 \mathrm{~g}$ three times daily for at least 3 days, followed by $1.5 \mathrm{~g}$ three times daily [3]. Another trial evaluated the novel drug AB103, studied also for sepsis, which impairs T-cell activation by blocking the binding of superantigen exotoxins to the CD28 receptor on $\mathrm{T}$ - helper1 lymphocytes [4]. Two doses $(0.5 \mathrm{mg} / \mathrm{kg}$ and $0.25 \mathrm{mg} / \mathrm{kg})$ were investigated against the placebo. The third trial assessed intravenous immunoglobulin at a dose of $25 \mathrm{~g} /$ day, given for 3 consecutive days, versus a placebo [5].

In all trials, no difference was detected between groups regarding the primary outcome measures. The quality of evidence was assessed as low to very low; this implies uncertainty in these results. Adverse events, secondary outcomes, and median survival times are summarized in Table 1. None of the trials assessed long-term morbidity as defined in the review protocol [1]. 
Table 1. A summary of trials included in the Cochrane review [1].

\begin{tabular}{|c|c|c|c|}
\hline \multirow[t]{2}{*}{ Characteristic } & \multicolumn{3}{|l|}{ Trials } \\
\hline & $\begin{array}{l}\text { MXF }^{\mathrm{a}} \text { vs AM-CL } \\
\text { al }{ }^{\mathrm{b}} \text {, Vick-Fragoso et }\end{array}$ & AB103 vs placebo, Bulger et al [4] & IVIG $^{\mathrm{c}}$ vs placebo, Madsen et al [5] \\
\hline \multirow[t]{4}{*}{ Groups } & 1. MXF $400 \mathrm{mg}$ once daily & 1. $\mathrm{AB} 1030.5 \mathrm{mg} / \mathrm{kg}$ & \multirow{4}{*}{$\begin{array}{l}\text { 1. IVIG } 25 \mathrm{~g} / \text { day for } 3 \text { consecutive } \\
\text { days } \\
\text { 2. Placebo }\end{array}$} \\
\hline & \multirow{3}{*}{$\begin{array}{l}\text { 2. AM-CL } 3 \mathrm{~g} \text { three times daily for at } \\
\text { least } 3 \text { days followed by } 1.5 \mathrm{~g} \text { three } \\
\text { times daily }\end{array}$} & 2. $\mathrm{AB} 1030.25 \mathrm{mg} / \mathrm{kg}$ & \\
\hline & & 3. Placebo & \\
\hline & & $\begin{array}{l}\text { Single intravenous dose within } 6 \\
\text { hours after diagnosis }\end{array}$ & \\
\hline Participants, $n$ & $\begin{array}{l}54 \text { (MXF group: } n=36 ; \text { AM-CL } \\
\text { group: } n=18 \text { ) }\end{array}$ & $\begin{array}{l}43 \text { (AB } 103 \text { group: } n=32 ; \text { placebo } \\
\text { group: } n=11 \text { ) }\end{array}$ & $\begin{array}{l}100 \text { (IVIG group: } n=50 \text {; } \\
\text { placebo group: } n=50 \text { ) }\end{array}$ \\
\hline Overall risk of bias & $\begin{array}{l}\text { High (attrition, imbalance, perfor- } \\
\text { mance, detection) }\end{array}$ & Moderate (attrition) & High (attrition, imbalance) \\
\hline \multicolumn{4}{|l|}{ Primary outcomes } \\
\hline Mortality within 30 days & $\begin{array}{l}\text { No difference }\left(\mathrm{RR}^{\mathrm{d}} 3.00,95 \% \mathrm{CI}\right. \\
0.39-23.0)\end{array}$ & $\begin{array}{l}\text { No difference (RR } 0.34,95 \% \text { CI } 0.05 \text { - } \\
2.16)\end{array}$ & $\begin{array}{l}\text { No difference (RR } 1.17,95 \% \text { CI } 0.42 \text { - } \\
3.23 \text { ) }\end{array}$ \\
\hline Certainty of evidence & Very low & Very low & Low \\
\hline $\begin{array}{l}\text { Proportion of patients } \\
\text { who experienced serious } \\
\text { adverse events }\end{array}$ & $\begin{array}{l}\text { Not specified; no difference (RR } 0.63 \text {, } \\
95 \% \text { CI 0.30-1.31) }\end{array}$ & $\begin{array}{l}\text { Not specified; no difference (RR } 1.49 \text {, } \\
95 \% \text { CI 0.52-4.27) }\end{array}$ & $\begin{array}{l}\text { Acute kidney injury, allergic reac- } \\
\text { tions, aseptic meningitis, hemolytic } \\
\text { anemia, thrombi, and infections; }\end{array}$ \\
\hline & & & $\begin{array}{l}\text { no difference (RR } 0.73 \text {, CI } 95 \% 0.32- \\
1.65)\end{array}$ \\
\hline Certainty of evidence & Very low & Very low & Low \\
\hline \multicolumn{4}{|l|}{ Secondary outcomes } \\
\hline $\begin{array}{l}\text { Survival time (median time } \\
\text { of death) }\end{array}$ & $\begin{array}{l}\text { Shorter in the MXF group ( } 10.5 \text { days } \\
\text { vs } 42 \text { days); no statistical analysis was } \\
\text { possible }\end{array}$ & Not specified & $\begin{array}{l}\text { Shorter in the IVIG group ( } 25 \text { days } \\
\text { vs } 49 \text { days); no statistical analysis was } \\
\text { possible }\end{array}$ \\
\hline $\begin{array}{l}\text { Assessment of long - term } \\
\text { morbidity }\end{array}$ & Not specified & Not specified & $\begin{array}{l}\text { No difference in the median physical } \\
\text { component summary scores between } \\
\text { groups (mean adjusted difference } 1 \text {, } \\
95 \% \text { CI } 7-10 ; P=.81 \text { ) }\end{array}$ \\
\hline
\end{tabular}

${ }^{\mathrm{a}}$ MXF: moxifloxacin.

${ }^{\mathrm{b}} \mathrm{AM}-\mathrm{CL}$ : amoxicillin - clavulanate.

${ }^{\mathrm{c}}$ IVIG intravenous immunoglobulin.

${ }^{\mathrm{d}} \mathrm{RR}$ risk ratio.

The quality of the evidence was negatively impacted by attrition bias, indirectness due to the lack of a definition of NSTIs, small sample size, and underpowered analysis. The lack of high-quality evidence for this serious condition necessitates the need for larger, well-designed studies. A recent randomized controlled trial evaluated the efficacy of AB103 $0.5 \mathrm{mg} / \mathrm{kg}$ versus placebo when administered within 6 hours of NSTI diagnosis [6]. No significant improvement was found in the primary composite endpoint (28-day mortality, number of debridements, amputations after the first operation, and resolution of organ dysfunction) in intention to treat whereas there was in the per-protocol population [6]. Given the rarity of NSTIs and their complex diagnosis and management, prospective registries are encouraged to provide evidence for effective therapeutic approaches to improve morbidity and mortality.

\section{Conflicts of Interest}

BLA has served as a research investigator and/or scientific advisor to AbbVie and Skin Research Institute, LLC.

\section{Editorial notice}

The views expressed in this paper are those of the authors and in no way represent the Cochrane Library or Wiley.

This article is based on a Cochrane Review previously published in the Cochrane Database of Systematic Reviews 2018, Issue 5, DOI:10.1002/14651858.CD011680.pub2 (see www.cochranelibrary.com for information). Cochrane Reviews are regularly updated as new evidence emerges and in response to feedback, and Cochrane Database of Systematic Reviews should be consulted for the most recent version of the review. 


\section{References}

1. Hua C, Bosc R, Sbidian E, De Prost N, Hughes C, Jabre P, et al. Interventions for necrotizing soft tissue infections in adults. Cochrane Database Syst Rev 2018 May 31;5:CD011680 [FREE Full text] [doi: 10.1002/14651858.CD011680.pub2] [Medline: 29851032]

2. Levett D, Bennett MH, Millar I. Adjunctive hyperbaric oxygen for necrotizing fasciitis. Cochrane Database Syst Rev 2015 Jan 15;1:CD007937 [FREE Full text] [doi: 10.1002/14651858.CD007937.pub2] [Medline: 25879088]

3. Vick-Fragoso R, Hernández-Oliva G, Cruz-Alcázar J, Amábile-Cuevas CF, Arvis P, Reimnitz P, STIC Study Group. Efficacy and safety of sequential intravenous/oral moxifloxacin vs intravenous/oral amoxicillin/clavulanate for complicated skin and skin structure infections. Infection 2009 Oct;37(5):407-417. [doi: 10.1007/s15010-009-8468-x] [Medline: 19768381]

4. Bulger EM, Maier RV, Sperry J, Joshi M, Henry S, Moore FA, et al. A Novel Drug for Treatment of Necrotizing Soft-Tissue Infections: A Randomized Clinical Trial. JAMA Surg 2014 Jun;149(6):528-536. [doi: 10.1001/jamasurg.2013.4841] [Medline: 24740134]

5. Madsen MB, Hjortrup PB, Hansen MB, Lange T, Norrby-Teglund A, Hyldegaard O, et al. Immunoglobulin G for patients with necrotising soft tissue infection (INSTINCT): a randomised, blinded, placebo-controlled trial. Intensive Care Med 2017 Nov;43(11):1585-1593. [doi: 10.1007/s00134-017-4786-0] [Medline: 28421246]

6. Bulger EM, May AK, Robinson BRH, Evans DC, Henry S, Green JM, ACCUTE Study Investigators. A Novel Immune Modulator for Patients With Necrotizing Soft Tissue Infections (NSTI): Results of a Multicenter, Phase 3 Randomized Controlled Trial of Reltecimod (AB 103). Ann Surg 2020 Sep 01;272(3):469-478. [doi: 10.1097/SLA.0000000000004102] [Medline: 32657946]

\section{Abbreviations}

NSTI: necrotizing soft tissue infection

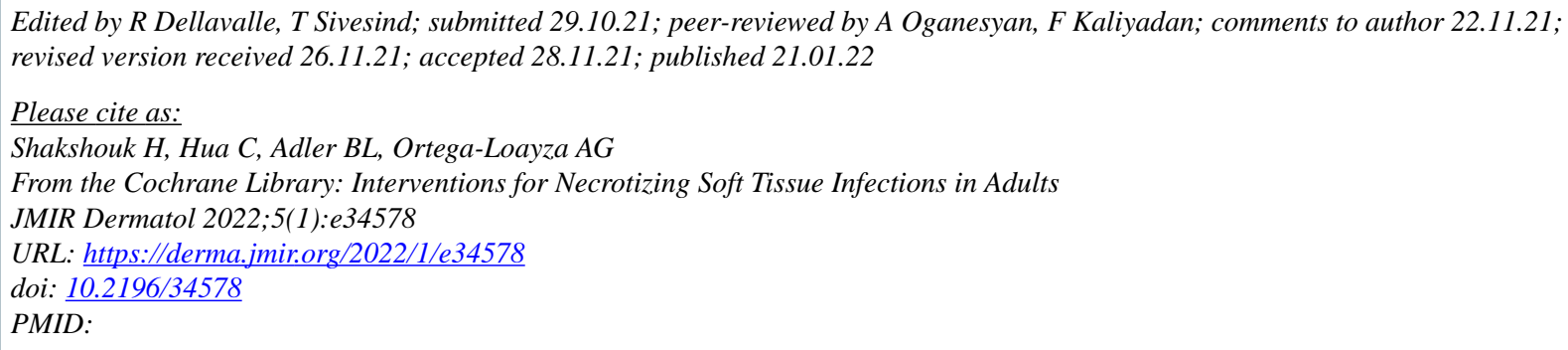

CHadir Shakshouk, Camille Hua, Brandon L Adler, Alex G Ortega-Loayza. Originally published in JMIR Dermatology (http://derma.jmir.org), 21.01.2022. This is an open-access article distributed under the terms of the Creative Commons Attribution License (https://creativecommons.org/licenses/by/4.0/), which permits unrestricted use, distribution, and reproduction in any medium, provided the original work, first published in JMIR Dermatology Research, is properly cited. The complete bibliographic information, a link to the original publication on http://derma.jmir.org, as well as this copyright and license information must be included. 